\title{
Nutritional Value of Apiaceae Seeds as Affected by 11 Species and 43 Cultivars
}

\author{
Nadezhda Golubkina ${ }^{1, *}$, Viktor Kharchenko ${ }^{1}$, Anastasia Moldovan ${ }^{1}$, Vladimir Zayachkovsky ${ }^{1}$, \\ Viktor Stepanov ${ }^{1}$, Viktor Pivovarov ${ }^{1}$, Agnieszka Sekara ${ }^{2}{ }^{\mathbb{D}}$, Alessio Tallarita ${ }^{3}$ and Gianluca Caruso $^{3}$ \\ 1 Federal Scientific Center of Vegetable Production, Selectsionnaya 14, VNIISSOK, Odintsovo District, \\ 143072 Moscow, Russia; kharchenkoviktor777@gmail.com (V.K.); nastiamoldovan@mail.ru (A.M.); \\ vladimir89854217114@mail.ru (V.Z.); vstepanov8848@mail.ru (V.S.); pivovarov@vniissok.ru (V.P.) \\ 2 Department of Horticulture, Faculty of Biotechnology and Horticulture, University of Agriculture, \\ 31-120 Krakow, Poland; agnieszka.sekara@urk.edu.pl \\ 3 Department of Agricultural Sciences, University of Naples Federico II, Naples, 80055 Portici, Italy; \\ lexvincentall@gmail.com (A.T.); gcaruso@unina.it (G.C.) \\ * Correspondence: segolubkina45@gmail.com
}

Citation: Golubkina, N.;

Kharchenko, V.; Moldovan, A.; Zayachkovsky, V.; Stepanov, V.;

Pivovarov, V.; Sekara, A.; Tallarita, A.; Caruso, G. Nutritional Value of Apiaceae Seeds as Affected by 11 Species and 43 Cultivars Horticulturae 2021, 7, 57. https://doi.org/10.3390/ horticulturae7030057

Academic Editor: Sergio

Ruffo Roberto

Received: 1 March 2021

Accepted: 19 March 2021

Published: 21 March 2021

Publisher's Note: MDPI stays neutral with regard to jurisdictional claims in published maps and institutional affiliations.

Copyright: (c) 2021 by the authors. Licensee MDPI, Basel, Switzerland. This article is an open access article distributed under the terms and conditions of the Creative Commons Attribution (CC BY) license (https:/ / creativecommons.org/licenses/by/ $4.0 /)$.

\begin{abstract}
The fragmentary literature data on Apiaceae seed antioxidant potential elicited a comparative evaluation work of seed biochemical profile between 11 species and 43 cultivars grown in similar conditions: anise, lovage, fennel, coriander, caraway, parsley, celery, dill, carrot, parsnip and chervil. Among the different solvents, temperature and duration regimes applied, $70 \% \mathrm{EtOH}, 80{ }^{\circ} \mathrm{C}$ and $1 \mathrm{~h}$ running showed the best extraction efficiency of antioxidants. Total antioxidant activity (AOA) decreased as follows: lovage $>$ anise $>$ parsley $>$ celery $>$ fennel $=$ dill $>$ coriander $>$ caraway $>$ parsnip $>$ carrot $>$ chervil. Lovage, anise and fennel demonstrated the highest levels of total phenolics (TP), AOA and potassium. A positive correlation was recorded between total dissolved solids (TDS) and K and between AOA and TP content $(\mathrm{r}=0.86$ and $\mathrm{r}=0.79$ respectively, at $p<0.001)$. Varietal differences in AOA and TP levels were much lower than those relevant to TDS, $\mathrm{K}$ and water soluble protein (WSP), while the highest differences were found for selenium (Se). Two parsley cultivars showed anomalously high Se content and four dill cultivars unusually high levels of TDS and potassium. A positive correlation arose between Se and WSP levels in parsley seeds $(r=0.85$ at $p<0.05)$.
\end{abstract}

Keywords: Apiaceae; seeds; antioxidants; potassium; total dissolved solids; protein

\section{Introduction}

Modern nutritiology is characterized by the significant expansion of food products and biologically active food supplements, based on substances produced at all stages of herbs' growth and development: seeds [1], sprouts [2,3], microgreens [4], all parts and tissues of mature plants, including agricultural wastes [5]. Among seeds of different crops, Apiaceae seeds are of special interest due to their wide utilization as spices containing high levels of essential oil [6] and their high value in traditional medicine [7].

The Apiaceae family includes more than 3500 species, among which celery, parsley, dill, coriander, carrot, parsnip, fennel, anise, caraway, lovage and chervil are the most common. Interestingly, all parts of the above Apiaceae representatives are edible and demonstrate high biological activity [1,6]. High levels of antioxidants in Apiaceae plants normalize digestion, express powerful antibiotic properties [7], increase immunity and have anticarcinogenic, cardioprotective and hypolipidemic effects. Celery and lovage seeds normalize spermatogenesis, while seeds of caraway, coriander, carrot and anise promote insulin production [8]. Carrot seed extracts possess cardio- and hepatoprotective effect, normalize cognitive function, decrease cholesterol level and show anti-bacterial, anti-fungal, anti-inflammatory, and analgesic effect and promote wound healing [9].

With the exception of the essential oil components of Apiaceae seeds, seed antioxidant system has been studied rather fragmentarily up to date. In this respect, the difficulty lies 
in the utilization need of seeds from numerous Apiaceae crops grown in similar conditions, as environment is known to cause a dominant effect on seed quality, and in particular on antioxidant status, protein and mineral content $[1,10]$. Previous studies of Apiaceae seed antioxidant status were carried out by: Christova-Bagdassarian et al. [11] on antioxidant status of fennel, anise, dill, coriander and caraway; Martins et al. [12] on phenolic content and antioxidant activity of anise and coriander; Wangensteen et al. [13] on phenolic content in coriander seeds; Marques and Farah [14] on anise phenolic profile. Unfortunately, all these works dealt only with a few representatives of Apiaceae family or used samples gathered from different geographical areas [12]. In the latter respect, the efficiency of seed utilization in medicine and as a functional food is determined to a large extent not only by species but also by cultivar peculiarities in accumulating antioxidants, proteins and minerals. Unfortunately, up to date no evaluation of antioxidant status differences between Apiaceae cultivars seed has been carried out, contrary to deep investigations of the mature plant antioxidant status [15] and the relationship between Apiaceae seed quality and N, P K content [16]. Taking into account the scant information available in the literature, the present investigation aimed to comparatively evaluate species and cultivar peculiarities in accumulating antioxidants and other biologically active compounds in seeds of 11 Apiaceae species, including 43 cultivars.

\section{Materials and Methods}

\subsection{Experimental Protocol and Growing Conditions}

A research was carried out in 2018 and 2019 at the experimental fields of Federal Scientific Center of Vegetable Production (Moscow region, Russia, 55 $39.51^{\prime} \mathrm{N}, 37^{\circ} 12.23^{\prime} \mathrm{E}$ ) for obtaining seeds from 11 Apiaceae species and 43 cultivars of the mentioned scientific Center selection. All the plants were grown in similar conditions, in order to minimize the effect of biotic and abiotic factors and to obtain reliable significance of species and varietal nutritional peculiarities.

Plants were grown on a sod-podzolic clay-loam soil with $\mathrm{pH}$ 6.8, 2.1\% organic matter, $1.1 \mathrm{~g} \mathrm{~kg}^{-1} \mathrm{~N}, 0.045 \mathrm{~g} \mathrm{~kg}^{-1} \mathrm{P}_{2} \mathrm{O}_{5}, 0.357 \mathrm{~g} \mathrm{~kg}^{-1} \mathrm{~K}_{2} \mathrm{O}$. Apiaceae collection included perennial/biennial and annual plants. The first group was represented by the following cultivars: Udalets and Maslichny, of fennel (Foeniculum vulgare Mill.); Lider, of lovage (Levisticum officinale Koch.); Elixir, Samurai, Atlant, Gribovsky, Zakhar, Egor, Dobrynya, Judinka, of leafy, stem and root celery (Apium graveolens L.); Sakharnaya, Zolushka, Nezhnost, Moskvichka, Breeze, Krasotka, of parsley (Petroselinum crispum L.); Krugly, Zhemchug, Bely aist, of parsnip (Pastinaca sativa L.); and Moskovskaya zimnya, $\mathrm{F}_{1}$, Nadezhda, Minor, Nantskaya 11, Riff $F_{1}$, Marlinka, Shantane, of carrot (Daucus carota subsp. sativus). The second group included the following cultivars: Gribovsky, Alligator, Rusich, Zontik, Spartak, Kibrai, Lesnogorodsky, Kulinar, Salut, of dill (Anethum graveolens L.); Stimul and prospect specimen, of coriander (Coriandrum sativum L.); Vitiaz, of anise (Pimpinella anisum L.); Peresvet, of caraway (Carum carvi L.); and prospect specimen of chervil (Anthriscus cerefolium-L.Hoffm.) (21-20; 22-20; 24-20).

Seed harvesting was carried out manually at different dates depending on the species and cultivar peculiarities: on 15 to 31 August for carrot and parsnip; at the dates reported in Table S1 for the other species and cultivars. All harvested seeds were ripened in a stem dryer and kept at $+10{ }^{\circ} \mathrm{C}$ in refrigerator prior to analysis.

As the parameters analyzed may greatly depend on meteorological conditions, seed position inside the umbrella [16], plant density and agrochemicals used [17], a two-year experiment (2018-2019) was carried out using the same technical management for plant cultivation, seed collection and storage [18].

Mean values of temperature $\left({ }^{\circ} \mathrm{C}\right)$ and rainfall in 2018 and 2019 are presented in Table 1. 
Table 1. Mean temperature and rainfall in 2018-2019.

\begin{tabular}{ccccc}
\hline \multirow{2}{*}{ Month } & \multicolumn{2}{c}{$\mathbf{2 0 1 8}$} & \multicolumn{2}{c}{2019} \\
\cline { 2 - 5 } & $\begin{array}{c}\text { Mean Temperature } \\
\left({ }^{\circ} \mathbf{C}\right)\end{array}$ & Rainfall (mm) & $\begin{array}{c}\text { Mean Temperature } \\
\left({ }^{\circ} \mathbf{C}\right)\end{array}$ & Rainfall (mm) \\
\hline May & 16.2 & 61 & 16.3 & 57 \\
June & 17.3 & 56 & 19.6 & 64 \\
July & 20.5 & 92 & 16.8 & 69 \\
August & 19.8 & 28 & 16.4 & 57 \\
\hline
\end{tabular}

To eliminate the influence of environmental conditions on the results, equal amounts (10 g) of seeds of 2018 and 2019 harvest were weighed, mixed and used for the analysis, prior to which the seeds were dried to constant weight at $70{ }^{\circ} \mathrm{C}$ and homogenized using a Kenwood dough mixer (Model A 907 D).

\subsection{Total Dissolved Solids (TDS)}

TDS were determined in water extracts using TDS-3 conductometer (HM Digital, Inc., Seoul, Korea). About half a g of seed powder homogenate was ground in a mortar with $50 \mathrm{~mL}$ distilled water and left at room temperature for $1 \mathrm{~h}$. The concentration of dissolved solids determined in water solution by conductometer was re-calculated per kg d.w. using the formula:

$$
\operatorname{TDS}\left(\mathrm{mg} \cdot \mathrm{kg}^{-1} \text { d.w. }\right)=\mathrm{A} \times 50: \mathrm{a},
$$

where $\mathrm{A}$ is the conductometer reading in $\mathrm{mg} \mathrm{L}^{-1}$;

50: extract volume $(\mathrm{mL})$;

a: seed powder weight $(\mathrm{g})$.

\subsection{Total Polyphenols (TP)}

Total polyphenols were determined in $70 \%$ ethanol extract using the Folin-Ciocalteu colorimetric method as previously described [19]. One gram of dry seed homogenates was extracted with $20 \mathrm{~mL}$ of $70 \%$ ethanol at $80^{\circ} \mathrm{C}$ for $1 \mathrm{~h}$. The mixture was cooled down and quantitatively transferred to a volumetric flask, and the volume was adjusted to $25 \mathrm{~mL}$. The mixture was filtered through filter paper, and $1 \mathrm{~mL}$ of the resulting solution was transferred to a $25 \mathrm{~mL}$ volumetric flask, to which $2.5 \mathrm{~mL}$ of saturated $\mathrm{Na}_{2} \mathrm{CO}_{3}$ solution and $0.25 \mathrm{~mL}$ of diluted (1:1) Folin-Ciocalteu reagent were added. The volume was brought to $25 \mathrm{~mL}$ with distilled water. One hour later the solutions were analyzed through a spectrophotometer (Unico 2804 UV, Suite E Dayton, NJ, USA), and the concentration of polyphenols was calculated according to the absorption of the reaction mixture at $730 \mathrm{~nm}$. As an external standard, $0.02 \%$ gallic acid was used.

\subsection{Antioxidant Activity $(A O A)$}

The antioxidant activity of seeds was assessed using a redox titration method [19] via titration of $0.01 \mathrm{~N} \mathrm{KMnO}_{4}$ solution with ethanolic extracts of dry samples, produced as described in the Section 2.3. The reduction of $\mathrm{KMnO}_{4}$ to colorless $\mathrm{Mn}^{+2}$ in this process reflects the quantity of antioxidants dissolvable in $70 \%$ ethanol. The values were expressed in $\mathrm{mg}$ gallic acid equivalents (GAE) $\mathrm{g}^{-1}$ d.w.

\subsection{Selenium}

Selenium was analyzed using the fluorimetric method previously described for tissues and biological fluids [20]. About $0.1 \mathrm{~g}$ of dried homogenized samples were digested via sequential heating with a mixture of $1.5 \mathrm{~mL}$ nitric-chloral acids $(10: 7)$ at $120^{\circ} \mathrm{C}(1 \mathrm{~h}), 150{ }^{\circ} \mathrm{C}$ $(1 \mathrm{~h})$ and $180^{\circ} \mathrm{C}(1 \mathrm{~h})$. To eliminate traces of nitric acid, the samples were heated during 10 min at $150{ }^{\circ} \mathrm{C}$ with 2 drops of $30 \% \mathrm{H}_{2} \mathrm{O}_{2}$. Subsequent reduction of selenate $\left(\mathrm{Se}^{+6}\right)$ to selenite $\left(\mathrm{Se}^{+4}\right)$ was achieved via heating of samples with $1 \mathrm{~mL}$ solution of $6 \mathrm{~N} \mathrm{HCl}$ at $120^{\circ} \mathrm{C}$ during $10 \mathrm{~min}$. The formation of a complex between $\mathrm{Se}^{+4}$ and 2,3-diaminonaphtalene 
(DAN) was elicited at $53{ }^{\circ} \mathrm{C}(30 \mathrm{~min})$ using $1 \mathrm{mg} \mathrm{mL}^{-1}$ solution of DAN in $1 \% \mathrm{HCl}$. After cooling, the obtained piazoselenol solution was extracted with $3 \mathrm{~mL}$ of hexane and the extracts were subjected to fluorescence analysis at $519 \mathrm{~nm} \lambda$ emission and $376 \mathrm{~nm} \lambda$ excitation (Fluorimeter 02-4M, Lumex marketing, St. Petersburg, Russia). Each determination was done in triplicate. The precision of the results was verified using a reference standardlyophilized cabbage in each determination with Se concentration of $150 \mu \mathrm{g} \cdot \mathrm{kg}^{-1} \mathrm{~d} . \mathrm{w}$.

\subsection{Water Soluble Protein}

Water soluble protein levels were detected spectrophotometrically using the Bradford method based on utilization of Coomassie Brilliant Blue 250 and $0.05 \mathrm{M}$ Tris buffer, at $\mathrm{pH} 8$ [21]. Half a g of homogenized seed powder was carefully ground in a mortar with $15 \mathrm{~mL}$ of freshly prepared Tris buffer and left at room temperature for phases separation (about $1 \mathrm{~h}$ ). One hundred $\mu \mathrm{l}$ of the resulting supernatant was mixed with $0.9 \mathrm{~mL}$ of Tris buffer and $3 \mathrm{~mL}$ of Coomassie reagent and the reaction mixtures were subjected to spectrophotometer for the determination of absorption value at $595 \mathrm{~nm}$. Inner standardbovine albumin (Sigma).

\subsection{Potassium (K)}

Potassium content was determined by an ionomer Expert-001 (Econix, Russia), using ion selective electrode on water extracts of seeds ( $1 \mathrm{~g}$ of seed homogenate per $50 \mathrm{~mL}$ of distilled water).

\subsection{Statistical Analysis}

Data were processed by analysis of variance and mean separations were performed through the Duncan multiple range test, with reference to 0.05 probability level, using SPSS software version 21. Data expressed as percentage were subjected to angular transformation before processing.

\section{Results and Discussion}

\subsection{Total Dissolved Solids (TDS), Potassium (K) and Water Soluble Protein Content (WSP)}

Water extracts of seeds may provide an important information about seed quality, in particular potassium and soluble protein content. Highly useful integral indicator, the so called TDS, may be successfully applied for related characteristics both of seeds and plant parts [22].

Despite significant species differences in TDS, K and WSP levels, the mean values of these parameters were similar in seeds of both annual and biennial/perennial Apiaceae plants (Tables 2 and 3).

The highest seed TDS levels were recorded in fennel, lovage and anise and the lowest in carrot and chervil. The analysis of TDS and $\mathrm{K}$ variations allowed to identify several dill cultivars (Aligator, Spartak, Kibray, Salut) with anomalously high levels of the above parameters: TDS from 32.3 to $38.8 \mathrm{~g} \mathrm{~kg}^{-1}$ d.w. and $\mathrm{K}$ levels from 20.4 to $25.2 \mathrm{~kg}^{-1}$ d.w., whereas the celery cultivar Atlant (stem form) demonstrated unusually high levels of TDS (46.2 $\mathrm{g} \mathrm{kg}^{-1}$ d.w) and potassium content $\left(20.5 \mathrm{~g} \mathrm{~kg}^{-1}\right.$ d.w). Overall, TDS and K content of Apiaceae seeds showed a significant positive correlation $(\mathrm{r}=0.86$ at $p<0.001$; Figure 1), which suggests that $\mathrm{K}$ derivatives are the main components of Apiaceae seed water soluble compounds accounting for about $50 \%$ of the TDS. Furthermore, taking into account the simplicity of TDS determination the latter can be recommended as a fast method for implementation of potassium content comparative evaluation in seeds of agricultural crops. 
Table 2. Weight, total dissolved solids (TDS), potassium and water-soluble protein (WSP) content in seeds of perennial and biennial Apiaceae plants.

\begin{tabular}{|c|c|c|c|c|c|}
\hline Species & Cultivar & TDS (g kg ${ }^{-1}$ d.w.) & K (g kg ${ }^{-1}$ d.w.) & WSP (\%) & $\begin{array}{l}\text { Weight of } 1000 \\
\text { Seeds (g) }\end{array}$ \\
\hline \multirow{2}{*}{ Fennel } & Udalets & $45.45^{a}$ & $19.28^{a}$ & $4.1^{\mathrm{b}}$ & $3.8^{b}$ \\
\hline & № $15-07$ & $37.20^{b}$ & $15.93^{b}$ & $6.4^{\mathrm{a}}$ & $6.1^{\mathrm{a}}$ \\
\hline Lovage & Leader & $36.90^{\mathrm{b}}$ & $14.17^{b}$ & $6.1^{a}$ & $3.0^{c}$ \\
\hline \multirow{3}{*}{ Leafy celery } & Elixir & $21.90^{\mathrm{d}}$ & $11.28^{c}$ & $2.27^{c, d}$ & $0.5^{j}$ \\
\hline & Samurai & $23.75^{\mathrm{d}, \mathrm{e}}$ & $11.27^{c}$ & $2.53^{c}$ & $0.6^{j}$ \\
\hline & Zakhar & $21.25^{\mathrm{d}}$ & $11.50^{c}$ & $2.32^{c, d}$ & $0.4^{\mathrm{k}}$ \\
\hline \multirow{2}{*}{ Stem celery } & Atlant & $46.15^{\mathrm{a}}$ & $20.48^{\mathrm{a}}$ & $2.0^{\mathrm{d}, \mathrm{e}}$ & $0.5^{j}$ \\
\hline & Gribovsky & $33.00^{b, c}$ & $17.86^{\mathrm{a}}$ & $1.19^{g}$ & $0.4^{\mathrm{k}}$ \\
\hline \multirow{3}{*}{ Root celery } & Egor & $28.85^{c}$ & $13.04^{b, c}$ & $1.59^{\mathrm{f}}$ & $0.5^{\mathrm{j}}$ \\
\hline & Dobrynya & $27.05^{\mathrm{c}, \mathrm{e}}$ & $12.69^{b, c}$ & $1.59^{f}$ & $0.6^{j}$ \\
\hline & Judinka & $33.10^{b, c}$ & $19.71^{\mathrm{a}}$ & $1.0^{\mathrm{g}}$ & $0.4^{\mathrm{k}}$ \\
\hline \multirow{3}{*}{ Leafy parsley } & Nezhnost & $32.15^{b}$ & $20.62^{a}$ & $1.56^{f}$ & $1.9^{\mathrm{d}}$ \\
\hline & Moskvichka & $18.20^{f}$ & $9.20^{\mathrm{d}}$ & $1.75^{\mathrm{e}, \mathrm{f}}$ & $1.8^{\mathrm{d}, \mathrm{e}}$ \\
\hline & Breeze & $28.35^{c}$ & $14.00^{b}$ & $1.81^{\mathrm{e}, \mathrm{f}}$ & $1.6^{\mathrm{e}}$ \\
\hline Curly parsley & Krasotka & $29.90^{c}$ & $20.64^{\mathrm{a}}$ & $1.7^{\mathrm{e}, \mathrm{f}}$ & $1.3^{\mathrm{f}}$ \\
\hline \multirow{2}{*}{ Root parsley } & Sakharnaya & $32.55^{b, c}$ & $17.73^{\mathrm{a}}$ & $1.7^{\mathrm{e}, \mathrm{f}}$ & $1.2^{\mathrm{f}, \mathrm{g}}$ \\
\hline & Zolushka & $18.95^{\mathrm{f}}$ & $9.06^{\mathrm{d}}$ & $1.77^{\mathrm{e}}$ & $1.3^{f}$ \\
\hline \multirow{3}{*}{ Parsnip } & Krugly & $21.05^{\mathrm{d}}$ & $14.33^{b}$ & $1.72^{\mathrm{e}, \mathrm{f}}$ & $6.5^{a}$ \\
\hline & Bely aist & $22.20^{\mathrm{d}}$ & $13.09^{b, c}$ & $1.8^{\mathrm{e}}$ & $7.1^{\mathrm{a}}$ \\
\hline & Zhemchug & $22.70^{\mathrm{d}}$ & $13.30^{b, c}$ & $1.96^{\mathrm{d}, \mathrm{e}}$ & $6.4^{\mathrm{a}}$ \\
\hline \multirow{8}{*}{ Carrot } & Moskovskaya zimnya & $19.40^{f}$ & $5.60^{\mathrm{e}}$ & $1.2 \mathrm{~g}$ & $1.0 \mathrm{~g}$ \\
\hline & F1 Nadezhda & $15.15 \mathrm{~g}$ & $8.16^{\mathrm{d}}$ & $1.18^{g}$ & $1.2^{\mathrm{f}, \mathrm{g}}$ \\
\hline & Minor & 16.25 & $8.95^{\mathrm{d}}$ & $1.2 \mathrm{~g}$ & $1.6^{\mathrm{e}}$ \\
\hline & Nantskaya-11 & $14.50 \mathrm{~g}, \mathrm{~h}$ & $9.56^{\mathrm{d}}$ & $1.28^{\mathrm{g}}$ & $1.3^{\mathrm{f}}$ \\
\hline & F1 Riff & $12.45^{h}$ & $6.91^{\mathrm{d}}$ & $1.25^{\mathrm{g}}$ & $2.1^{\mathrm{d}}$ \\
\hline & Marlinka & $12.40^{\mathrm{h}}$ & $6.93^{\mathrm{d}}$ & $1.2 \mathrm{~g}$ & $1.6^{\mathrm{e}}$ \\
\hline & Shantane & $18.75^{\mathrm{f}}$ & $9.27^{\mathrm{d}}$ & $1.2^{\mathrm{g}}$ & $1.3^{\mathrm{f}}$ \\
\hline & $\mathrm{CV}(\%)$ & 30.2 & 32.0 & 40.0 & 71.4 \\
\hline
\end{tabular}

CV: coefficient of variation. Within each column, values with the same letters do not differ significantly according to Duncan test at $p<0.05$.

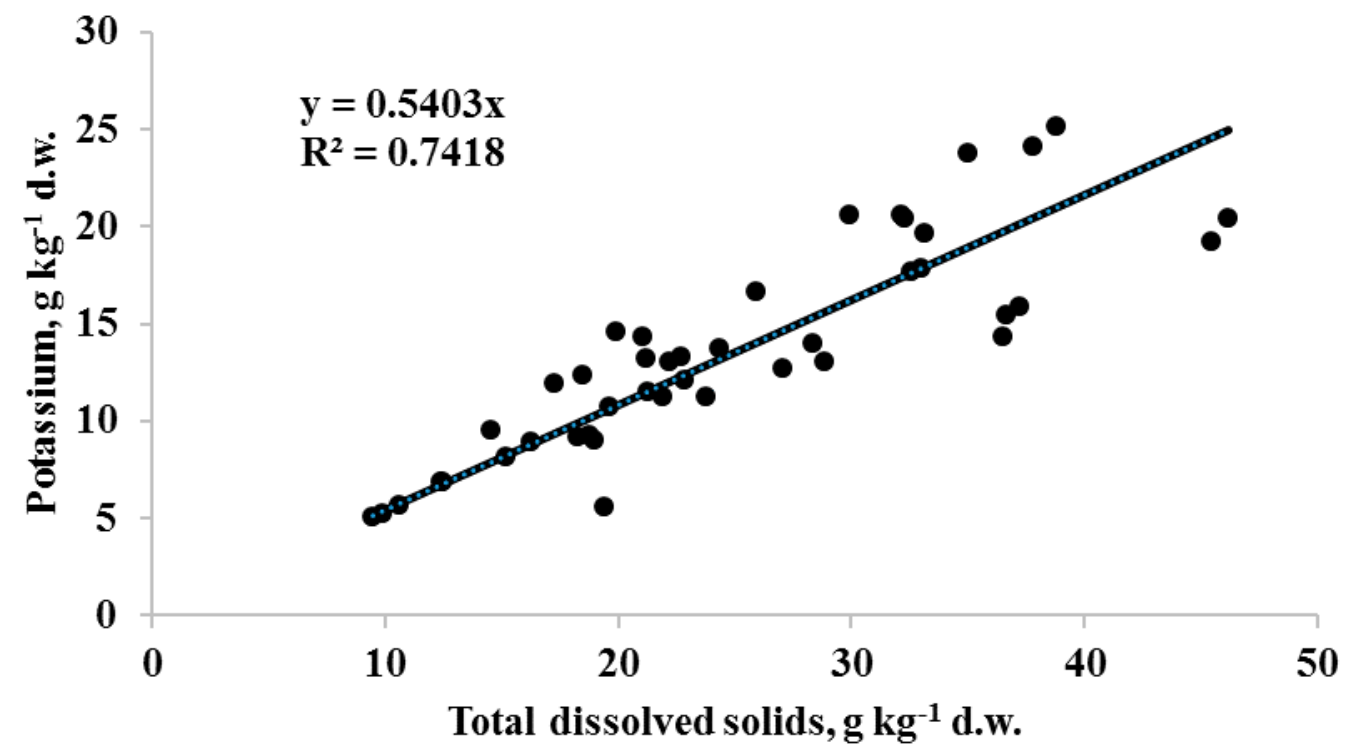

Figure 1. Correlation between potassium and total dissolved solids (TDS) content in Apiaceae seeds. $(\mathrm{r}=0.86$ at $p<0.001 ; n=43)$. 
Table 3. Weight, total dissolved solids (TDS), potassium and water-soluble protein (WSP) content in seeds of annual Apiaceae plants.

\begin{tabular}{|c|c|c|c|c|c|}
\hline Species & Cultivar & TDS (g kg ${ }^{-1}$ d.w.) & K (g kg ${ }^{-1}$ d.w.) & WSP (\%) & $\begin{array}{l}\text { Weight of } 1000 \\
\text { Seeds (g) }\end{array}$ \\
\hline Anise & Vityaz & $36.65^{a}$ & $15.47^{\mathrm{d}, \mathrm{e}}$ & $6.3^{a}$ & $2.4^{b}$ \\
\hline \multirow{9}{*}{ Dill } & Alligator & $37.75^{\mathrm{a}}$ & $24.17^{a}$ & $1.1^{\mathrm{e}}$ & $1.4^{\mathrm{e}, \mathrm{f}}$ \\
\hline & Spartak & $38.80^{\mathrm{a}}$ & $25.20^{\mathrm{a}}$ & $1.06^{\mathrm{e}}$ & $1.6^{\mathrm{d}, \mathrm{e}}$ \\
\hline & Zontik & $21.15^{b, c}$ & $13.23^{\mathrm{e}}$ & $1.43^{\mathrm{c}, \mathrm{d}}$ & $1.2^{\mathrm{f}, \mathrm{g}}$ \\
\hline & Kibray & $32.25^{\mathrm{a}}$ & $20.44^{b, c}$ & $1.08^{\mathrm{e}}$ & $1.3^{\mathrm{e}, \mathrm{f}}$ \\
\hline & Lesnogorodsky & $24.30^{b}$ & $13.77^{\mathrm{e}}$ & $1.23^{\mathrm{d}}$ & $1.8^{\mathrm{c}, \mathrm{d}}$ \\
\hline & Salut & $35.00^{\mathrm{a}}$ & $23.83^{a, b}$ & $1.43^{\mathrm{c}, \mathrm{d}}$ & $1.1^{\mathrm{g}}$ \\
\hline & Culinar & $22.80^{b, c}$ & $12.10^{\mathrm{e}}$ & $1.14^{\mathrm{e}}$ & $2.1^{\mathrm{b}}$ \\
\hline & Gribovsky & $19.60 \mathrm{ccd}$ & $10.77^{\mathrm{e}}$ & $1.06^{\mathrm{e}}$ & $2.0^{b, c}$ \\
\hline & Rusich & $18.45^{\mathrm{d}}$ & $12.39^{\mathrm{e}}$ & $1.48^{\mathrm{c}}$ & $1.5^{\mathrm{e}}$ \\
\hline \multirow{2}{*}{ Coriander } & Stimul & $17.25^{\mathrm{d}}$ & $11.98^{\mathrm{e}}$ & $5.3^{a}$ & $5.2^{\mathrm{a}}$ \\
\hline & № 07-19 & $25.90^{b}$ & $16.68^{c, d}$ & $5.8^{a}$ & $5.4^{\mathrm{a}}$ \\
\hline Caraway & Peresvet & $19.85^{\mathrm{c}, \mathrm{d}}$ & $14.59^{\mathrm{d}, \mathrm{e}}$ & $4.2^{b}$ & $2.2^{b}$ \\
\hline \multirow{4}{*}{ Chervil } & №21-20 & $9.85^{\mathrm{e}}$ & $5.30^{f}$ & $1.66^{\mathrm{c}}$ & $1.8^{\mathrm{c}, \mathrm{d}}$ \\
\hline & №22-20 & $10.60^{\mathrm{e}}$ & $5.70^{f}$ & $1.49^{c}$ & $1.7^{\mathrm{c}, \mathrm{d}}$ \\
\hline & №24-20 & $9.45^{\mathrm{e}}$ & $5.09^{\mathrm{f}}$ & $2.30^{\mathrm{b}}$ & $2.1^{\mathrm{c}}$ \\
\hline & $\mathrm{CV} \%$ & 31.6 & 31.3 & 66.7 & 40.9 \\
\hline
\end{tabular}

CV: coefficient of variation. Within each column, values with the same letters do not differ significantly according to Duncan test at $p<0.05$.

The highest differences in seed TDS and $\mathrm{K}$ levels were recorded between dill, celery and parsley cultivars, while seeds of 8 celery cultivars demonstrated the highest variations in protein content (Tables 2 and 3). The latter phenomenon is connected with morphological differences between leafy, stalk and root celery forms, with the highest seed WSP levels in leafy forms (Tables 2 and 3). Notably, carrot, parsley and parsnip seeds showed the lowest variability in WSP content between cultivars.

The content of water soluble proteins (WSP) in seeds is considered an important aspect of N, C and S supply, as these compounds are known to demonstrate enhanced biological activity and bioavailability [23]. Their concentration is an important parameter of seed germination [24], and their content increase in growing plants reflects the stress degree. Tables 2 and 3 data indicate that water soluble protein levels in anise, lovage, fennel and coriander thrice exceeded the mean level recorded in all Apiaceae seeds studied, whereas the WSP median reached $1.46 \%$ value both in seeds of annual and biennial/perennial plants.

Both annual and perennial/biennial Apiaceae plants were characterized by high variations in seed weight (Tables 2 and 3). Among the agricultural crops investigated, the highest 1000 seeds weight was recorded in coriander, fennel and parsnip (5.2 to $7.1 \mathrm{~g}$ ), and the lowest in celery ( 0.4 to $0.6 \mathrm{mg}$ ). These peculiarities are not related to WSP, K content and TDS values, whereas WSP concentration did not show a significant correlation with the above mentioned parameters.

\subsection{Antioxidants}

Antioxidant status of agricultural crops constantly attracts research attention in connection with their importance for the pharmacological value of the different plant parts [25]. According to the literature reports, Apiaceae seeds are rich not only in essential oils but also in antioxidants such as phenolics. Though most of the results have been obtained from studies on Apiaceae leaves, some investigations carried out on seeds have identified caffeic acid in dill, fennel and celery, cumaric acid in coriander and celery, resveratrol in parsley and dill and rutin in anise, caraway, fennel and dill (Table 4). A research of Faudale et al. [26] revealed great fluctuations both of the total phenolics content (TP) in fennel leaves and seeds and of polyphenol composition. The data presented in Table 3 
indicate that TP content in Apiaceae seeds showed a wide concentration range from 5-7 to $116 \mathrm{mg} \mathrm{GAE} \mathrm{g}^{-1}$ d.w., while a significantly narrower range was recorded in the present work (4.5-16.1 mg GAE $\mathrm{g}^{-1}$ d.w.) (Tables 4 and 5). The phenomenon may be connected with many factors: geographical and cultivar peculiarities, stress factors, different methods of extraction and calculation (per g of seeds or extracts d.w.). Indeed, Tomsone and Kruma [27] indicated that the method of TP extraction may result in values differing from each other by $100 \%$ in lovage seeds (Table 4). Similar results were obtained by Uddin et al. [28] in celery seeds, where TP content reached $63.46 \mathrm{mg} \mathrm{GAE} \mathrm{g}^{-1}$ d.w. in $\mathrm{MeOH}$ and only $36.6 \mathrm{mg} \mathrm{GAE}^{-1}$ d.w. in EtOH extract.

Table 4. Literature data relevant to polyphenol composition and content in seeds of Apiaceae plants.

\begin{tabular}{|c|c|c|c|c|}
\hline Species & Polyphenol Composition & Seed TP $* *$ & Extraction Conditions & References \\
\hline Lovage & No data available & $5.68-10.43$ & $95 \% \mathrm{EtOH}$ & [27] \\
\hline Fennel * & $\begin{array}{l}\text { Caffeic acid and quercetin } \\
\text { derivatives, rosmarinic acid }\end{array}$ & & $80 \% \mathrm{EtOH}$ sonication & [26] \\
\hline Anise & \multirow{4}{*}{ Rutin, tannin } & 46.17 & \multirow{4}{*}{$80 \% \mathrm{MeOH}$} & \multirow{4}{*}[11,29]{} \\
\hline Caraway & & 25.96 & & \\
\hline Fennel & & 115.96 & & \\
\hline \multirow{2}{*}{ Coriander } & & 17.04 & & \\
\hline & $\begin{array}{l}\text { p-hydroxybenzoic acid, cumarin; } \\
\text { p-cumaric acid }\end{array}$ & 15.55 & $\mathrm{MeOH}$ & [30] \\
\hline Caraway & & 3.99 & \multirow{2}{*}{$\begin{array}{c}50 \% \mathrm{EtOH}+ \\
0.1 \% \text { formic acid }\end{array}$} & \multirow{2}{*}{ [31] } \\
\hline Dill & & 0.94 & & \\
\hline \multirow[b]{2}{*}{ Celery } & $\begin{array}{l}\text { Gallic, Caffeic, Trans-ferulic, } \\
\text { o-cumaric acids }\end{array}$ & - & - & [32] \\
\hline & $\begin{array}{l}\text { caffeic acid,p-coumaric acid, } \\
\text { ferulic acid; apigenin, luteolin, } \\
\text { and kaempferol. }\end{array}$ & $63.46-36.60$ & $\mathrm{MeOH}$ & [28] \\
\hline \multirow[t]{2}{*}{ Parsley } & $\begin{array}{l}\text { Resveratrol, pyrogallol, salicylic } \\
\text { acids, benzoic acid, naringin }\end{array}$ & 91.29 & $\mathrm{MeOH}$ & [33] \\
\hline & No data & 67.25 & $\mathrm{MeOH}$ & [34] \\
\hline Dill & $\begin{array}{l}\text { cafeic acid, epicatechin, } \\
\text { resveratrol, rutin, quercetin, } \\
\text { kaempherol }\end{array}$ & 26.41 & $\mathrm{EtOH}, 60 \mathrm{~min}$ & [35] \\
\hline Carrot & No data available & 7.08 & $\mathrm{MeOH}$ & [36] \\
\hline Chervil & \multirow{2}{*}{\multicolumn{4}{|c|}{ No data available }} \\
\hline Parsnip & & & & \\
\hline
\end{tabular}

* leaves data; ** TP, total phenolics in $\mathrm{mg} \mathrm{GAE} \mathrm{g}^{-1}$ d.w.

Table 5. Seed total phenolics (TP), Se content and total antioxidant activity (AOA) of perennial and biennial Apiaceae plants.

\begin{tabular}{|c|c|c|c|c|}
\hline Species & Cultivar & $\begin{array}{c}\text { AOA } \\
\text { mg GAE }^{-1} \text { d.w. }\end{array}$ & $\begin{array}{c}\text { TP } \\
\text { mg GAE } \text { g }^{-1} \text { d.w. }\end{array}$ & $\begin{array}{c}\text { Se } \\
\mu \mathrm{g} \mathrm{kg}{ }^{-1} \text { d.w. }\end{array}$ \\
\hline Lovage & Leader & $61.2^{\mathrm{a}}$ & $16.1^{\mathrm{a}}$ & $26^{g}$ \\
\hline \multirow{3}{*}{ Leafy parsley } & Nezhnost & $54.1^{\mathrm{a}, \mathrm{b}}$ & $10.4^{\mathrm{e}}$ & $23^{g}$ \\
\hline & Mokvichka & $53.1^{\mathrm{a}, \mathrm{b}}$ & $12.5^{\mathrm{c}, \mathrm{d}}$ & $142^{\mathrm{a}}$ \\
\hline & Breeze & $55.3^{\mathrm{a}, \mathrm{b}}$ & $10.3^{\mathrm{e}}$ & $137^{\mathrm{a}}$ \\
\hline Curley parsley & Krasotka & $48.2^{b}$ & $9.4^{\mathrm{e}}$ & $23^{g}$ \\
\hline \multirow{2}{*}{ Root parsley } & Sakharnaya & $51.2^{a, b}$ & $10.0^{\mathrm{e}}$ & $22^{g}$ \\
\hline & Zolushka & $46.5^{b, c}$ & $10.3^{\mathrm{e}}$ & $89^{b}$ \\
\hline
\end{tabular}


Table 5. Cont.

\begin{tabular}{|c|c|c|c|c|}
\hline Species & Cultivar & $\begin{array}{c}\text { AOA } \\
\text { mg GAE }^{-1} \text { d.w. }\end{array}$ & $\begin{array}{c}\text { TP } \\
\text { mg GAE }^{-1} \text { d.w. }\end{array}$ & $\begin{array}{c}\text { Se } \\
\mu \mathrm{g} \mathrm{kg}^{-1} \text { d.w. }\end{array}$ \\
\hline \multirow{3}{*}{ Leafy celery } & Elixir & $37.5^{\mathrm{d}, \mathrm{e}}$ & $12.2^{\mathrm{c}, \mathrm{d}}$ & $26^{g}$ \\
\hline & Samurai & $37.5^{\mathrm{d}, \mathrm{e}}$ & $10.4^{\mathrm{e}}$ & $28^{g}$ \\
\hline & Zakhar & $36.2^{\mathrm{d}, \mathrm{e}}$ & $12.9^{b, c}$ & $25^{g}$ \\
\hline \multirow[t]{2}{*}{ Stem celery } & Atlant & $41.5^{\mathrm{c}, \mathrm{d}}$ & $13.0^{b, c}$ & $38^{d}$ \\
\hline & Gribovsky & $40.0^{c, d}$ & $13.0^{b, c}$ & $10^{\mathrm{j}}$ \\
\hline \multirow{3}{*}{ Root celery } & Egor & $42.5^{\mathrm{c}, \mathrm{d}}$ & $15.1^{\mathrm{a}, \mathrm{b}}$ & $30^{g}$ \\
\hline & Dobrynya & $40.9^{c, d}$ & $13.8^{\mathrm{a}, \mathrm{b}}$ & $25^{g}$ \\
\hline & Judinka & $40.0^{\mathrm{c}, \mathrm{d}}$ & $11.8^{\mathrm{c}, \mathrm{d}, \mathrm{e}}$ & $13^{j}$ \\
\hline \multirow[b]{2}{*}{ Fennel } & Udalets & $32.4^{\mathrm{e}}$ & $12.2^{\mathrm{c}, \mathrm{d}}$ & $10^{\mathrm{j}}$ \\
\hline & № 15-07 & $36.7^{\mathrm{d}, \mathrm{e}}$ & $14.3^{b}$ & $49^{\mathrm{c}, \mathrm{e}}$ \\
\hline \multirow{3}{*}{ Parsnip } & Krugly & $17.9^{\mathrm{f}, \mathrm{g}}$ & $9.8^{\mathrm{e}}$ & $37^{e}$ \\
\hline & Bely aist & $19.0^{\mathrm{f}}$ & $11.3^{\mathrm{d}, \mathrm{e}}$ & $51^{\mathrm{c}}$ \\
\hline & Zhemchug & $17.9^{\mathrm{f}, \mathrm{g}}$ & $9.5^{\mathrm{e}}$ & $31^{f, g}$ \\
\hline \multirow{8}{*}{ Carrot } & Moskovskaya zimnya & $15.6^{g, h}$ & $9.2^{\mathrm{e}, \mathrm{g}}$ & $56^{c}$ \\
\hline & F1 Nadezhda & $13.4^{h, j}$ & $7.6^{\mathrm{f}, \mathrm{g}}$ & $40^{\mathrm{d}, \mathrm{e}}$ \\
\hline & Minor & $15.8^{g, h}$ & $10.3^{\mathrm{e}}$ & $34^{\mathrm{f}}$ \\
\hline & Nantskaya-11 & $14.1^{\mathrm{h}}$ & $7.5^{f}$ & $33^{f}$ \\
\hline & F1 Riff & $12.5^{\mathrm{j}}$ & $6.5^{f}$ & $54^{c}$ \\
\hline & Marlinka & $13.0^{\mathrm{j}}$ & $7.8^{\mathrm{f}, \mathrm{g}}$ & $38^{d}$ \\
\hline & Shantane & $12.5^{\mathrm{j}}$ & $7.1^{\mathrm{f}}$ & $42^{\mathrm{d}, \mathrm{e}}$ \\
\hline & $\mathrm{CV} \%$ & 40.8 & 18.3 & 50.4 \\
\hline
\end{tabular}

CV: coefficient of variation. Within each column, values with the same letters do not differ significantly according to Duncan test at $p<0.05$.

In the latter respect, selection of appropriate solvent and temperature regime for the extraction of antioxidants seems to be decisive. We achieved appropriate comparisons with variations of temperature, solvent and duration of extraction on seeds of three Apiaceae species: lovage, showing the highest AOA and essential oil content, chervil with the lowest level of AOA and low level of essential oil content after seeds drying, and coriander occupying an intermediate position. Data presented in Figure 2 indicate that changes in AOA and TP displayed similar trends. In fact, comparison of AOA and TP values in seeds obtained in different extraction conditions demonstrated the least efficiency of EtOH both at ambient and high temperature. In all cases, dilution of alcohol with water significantly improved the efficiency of extraction, while the best results were obtained with $70 \% \mathrm{EtOH}$ and heating of the extracts at $80^{\circ} \mathrm{C}$ for one hour. Furthermore, increase of the extraction temperature not only increased the efficiency of the extraction, but also changed positively the proportion of TP referred to total AOA level. The latter phenomenon may be connected with the possible loss of essential oil, which also contributes the AOA level of extracts.

Taking into account the obtained results, utilization of $70 \% \mathrm{EtOH}$ at high temperature for a relatively short time was the best treatment for evaluating Apiaceae seed antioxidant status. In the latter conditions (Tables 5 and 6), the AOA values of Apiaceae seeds ranged from 12.5 to $61.2 \mathrm{mg} \mathrm{GAE} \mathrm{g}^{-1}$ d.w. for perennial/biennial plants and from 7.6 to $58.0 \mathrm{mg}$ GAE $g^{-1}$ d.w. for annual representatives. Species differences in AOA values reflected the following sequence: lovage, anise, parsley > celery, dill, fennel > parsnip, coriander, carrot, caraway > chervil and were not associated with the belonging of plants to annual or perennial/biennial groups. High antioxidant activity of anise seeds was in accordance with that reported earlier by Martins et al. [12]. On the other hand, a positive correlation between AOA and TP (Figure 3) makes the seed TP/AOA ratio a reliable indicator of plant antioxidant status. In this respect, parsnip, chervil, carrot and caraway are characterized by the highest TP input to AOA, while parsley, lovage, dill and anise by the lowest, and it may be partially connected with species differences in essential oil content and its composition. 


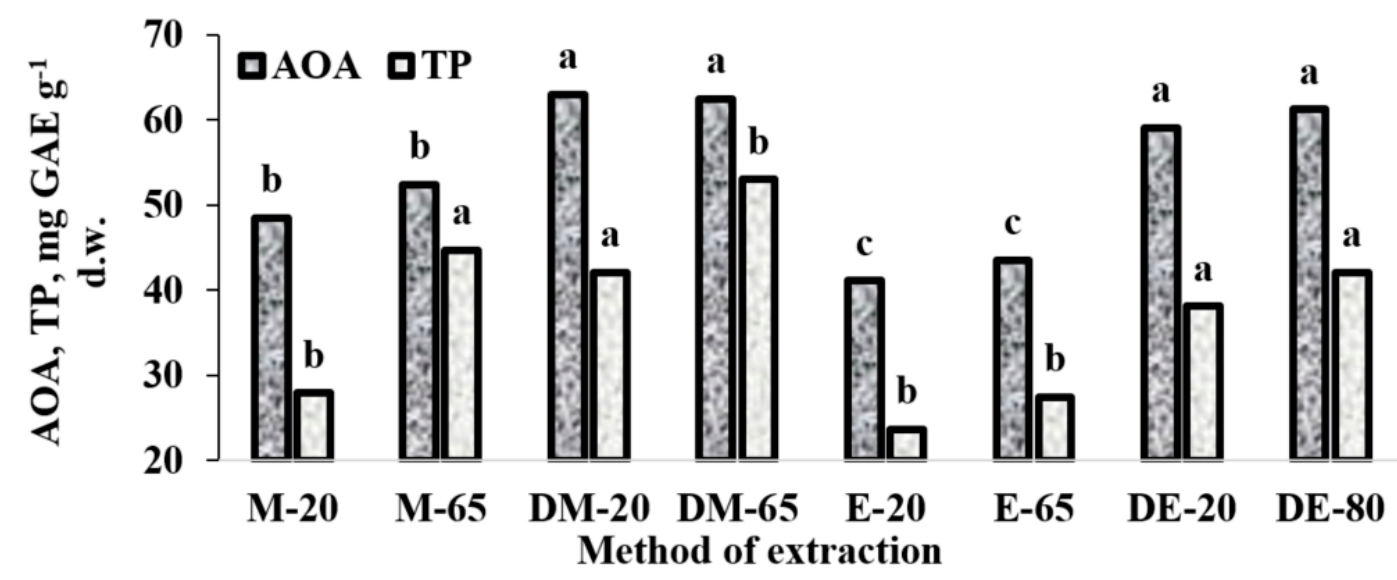

(a)

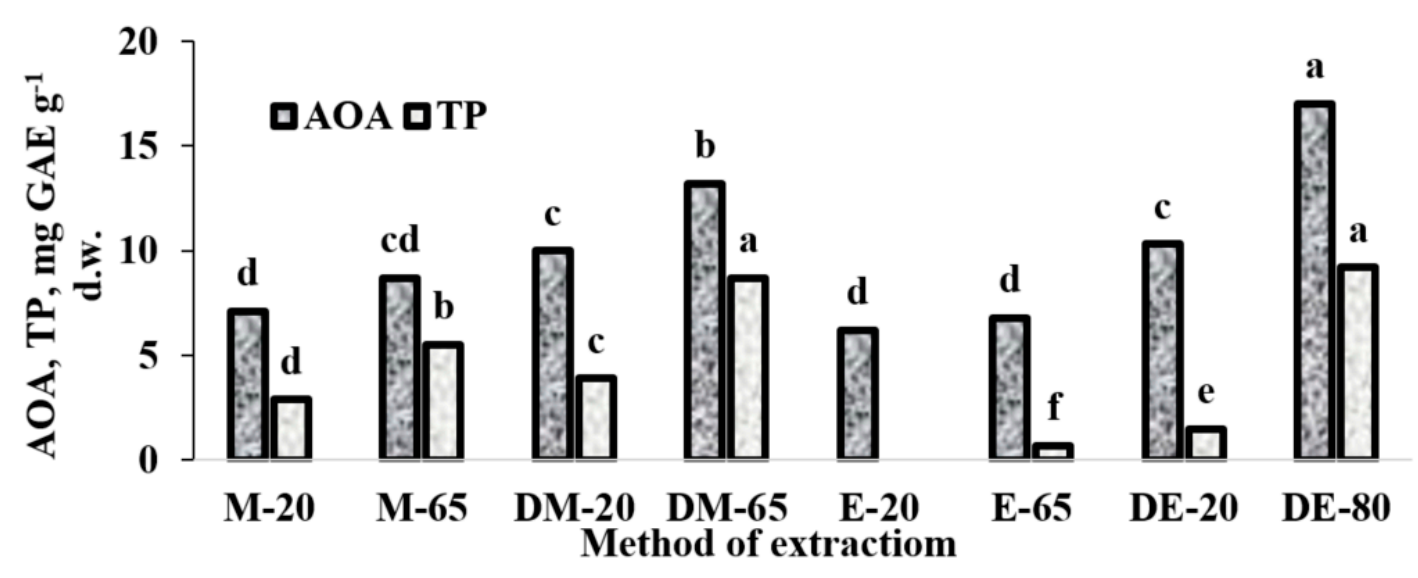

(b)

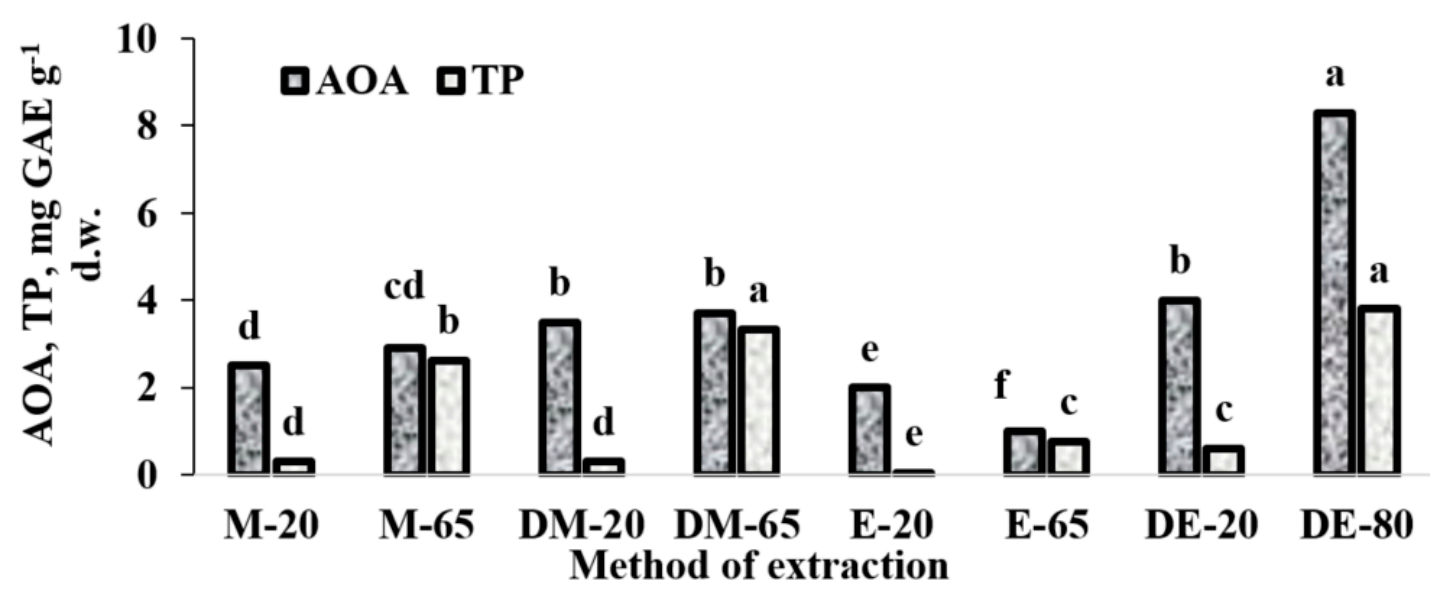

(c)

Figure 2. Effect of extraction conditions on total antioxidant activity (AOA) and total phenolics (TP) content in lovage (a), coriander (b) and chervil (c) seeds: (M-20)-methanol, $20^{\circ} \mathrm{C}$, $18 \mathrm{~h}$; (M-65)-methanol. $65^{\circ} \mathrm{C}, 1 \mathrm{~h}$; (DM-20)-70\% Methanol, $20{ }^{\circ} \mathrm{C}, 18 \mathrm{~h}$; (DM-65)—70\% Methanol, $65^{\circ} \mathrm{C}, 1 \mathrm{~h}$; (E-20)-ethanol, $20{ }^{\circ} \mathrm{C}, 18 \mathrm{~h}$; (E-65)-ethanol $65{ }^{\circ} \mathrm{C} 1 \mathrm{~h}$; (DE-20)-70\% ethanol, $20{ }^{\circ} \mathrm{C}, 18 \mathrm{~h}$; (DE-80)-70\% ethanol, $80^{\circ} \mathrm{C}, 1 \mathrm{~h}$. 
Table 6. Seed total phenolics (TP), Se content and total antioxidant activity (AOA) of annual Apiaceae plants.

\begin{tabular}{|c|c|c|c|c|}
\hline Species & Cultivar & $\begin{array}{c}\text { AOA } \\
{\text { mg GAE }{ }^{-1} \text { d.w. }}^{2}\end{array}$ & $\begin{array}{c}\text { TP } \\
\text { mg GAE } \text { g }^{-1} \text { d.w. }\end{array}$ & $\begin{array}{c}\text { Se } \\
\mu g \text { kg }^{-1} \text { d.w. }\end{array}$ \\
\hline Anise & Vityaz & $58.0^{\mathrm{a}}$ & $15.6^{a}$ & $41^{c}$ \\
\hline \multirow{9}{*}{ Dill } & Alligator & $26.7^{c}$ & $6.8^{\mathrm{e}}$ & $35^{\mathrm{e}}$ \\
\hline & Spartak & $29.4^{\mathrm{c}}$ & $8.3^{\mathrm{c}, \mathrm{d}}$ & $32 \mathrm{e}, \mathrm{f}$ \\
\hline & Zontik & $36.4^{\mathrm{b}}$ & $10.7^{b}$ & $45^{c}$ \\
\hline & Kibray & $37.4^{\mathrm{b}}$ & $10.1^{b, c}$ & $35^{\mathrm{e}}$ \\
\hline & Lesnogorodsky & $37.9^{b}$ & $8.5^{\mathrm{c}, \mathrm{d}}$ & $44^{\mathrm{c}, \mathrm{d}}$ \\
\hline & Salut & $38.3^{b}$ & $8.1^{\mathrm{d}, \mathrm{e}}$ & $45^{c}$ \\
\hline & Culinar & $38.3^{b}$ & $11.8^{\mathrm{b}}$ & $38^{\mathrm{d}, \mathrm{e}}$ \\
\hline & Gribovsky & $38.5^{b}$ & $10.9^{b}$ & $40^{\mathrm{c}, \mathrm{d}}$ \\
\hline & Rusich & $39.0^{\mathrm{b}}$ & $10.1^{b, c}$ & $44^{\mathrm{c}, \mathrm{d}}$ \\
\hline \multirow{2}{*}{ Coriander } & Stimul & $18.3^{\mathrm{d}}$ & $8.2^{\mathrm{c}, \mathrm{d}}$ & $27^{f, g}$ \\
\hline & № 07-19 & $17.0^{\mathrm{d}}$ & $7.8^{\mathrm{e}}$ & $28^{f, g}$ \\
\hline Caraway & Peresvet & $12.9^{\mathrm{e}}$ & $8.6^{c, d}$ & $25^{g}$ \\
\hline \multirow{4}{*}{ Chervil } & №21-20 & $8.3^{f}$ & $4.6^{\mathrm{f}}$ & $110^{a}$ \\
\hline & №22-20 & $9.8^{\mathrm{f}}$ & $4.9^{\mathrm{f}}$ & $85^{b}$ \\
\hline & №24-20 & $7.6^{\mathrm{f}}$ & $4.5^{\mathrm{f}}$ & $82^{b}$ \\
\hline & CV $(\%)$ & 38.4 & 22.2 & 31.2 \\
\hline
\end{tabular}

CV: coefficient of variation. Within each column, values with the same letters do not differ significantly according to Duncan test at $p<0.05$.

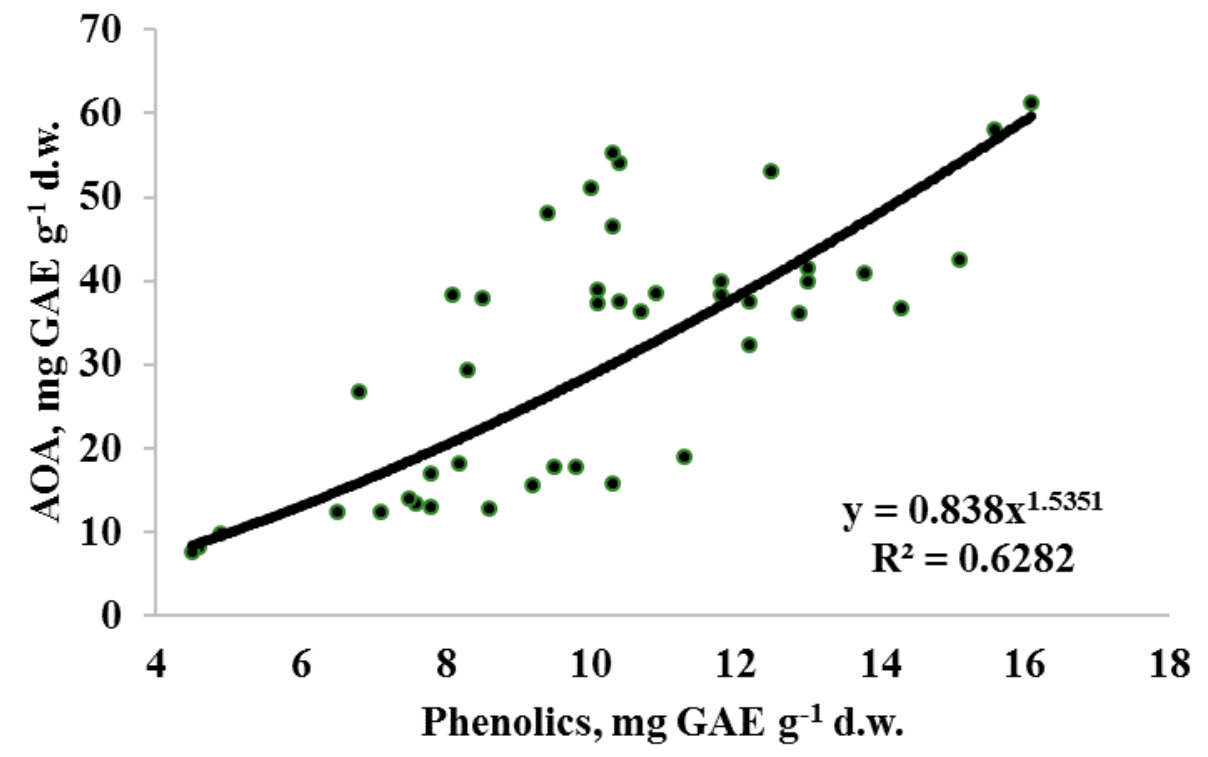

Figure 3. Correlation between total antioxidant activity (AOA) and total phenolics (TP) content in seeds of Apiaceae plants ( $\mathrm{r}=0.79$ at $p<0.001 ; n=43)$.

Among natural antioxidants, selenium plays a special role, as it is highly valuable in human organism due to its strong antioxidant activity and ability to protect against viral, cardiovascular diseases, cancer and covid infection [37]. However, this trace element is not essential for plants, though it demonstrates a protective effect against biotic and abiotic stresses [38]. Apiaceae plants belong to a group of plants highly sensitive to toxic Se concentrations (the so-called 'Se non accumulators'). Indeed, Se levels in Apiaceae seeds are low (Tables 5 and 6), which is in agreement with the above statement. On the other hand, a comparison of variation coefficients for AOA, TP, TDS, K, WSP and Se indicates lower CV values of AOA and TP compared to TDS, K and WSP, contrary to Se data with variation coefficient ranging from 11 to $70 \%$. Indeed, differences among cultivars in the studied 
parameters were highly expressed for Se in parsley and celery, while phenolics content in most cases was rather stable. Furthermore, the largest differences between cultivars for TP did not exceed $15 \%$ (dill seeds; Table 6). The highest levels of Se accumulation were recorded in Breeze and Moskvichka parsley cultivars (Table 4), which arises high prospects of these cultivars seed utilization as important functional food supplements characterized by high Se (137 to $142 \mu \mathrm{g} \mathrm{kg}{ }^{-1}$ d.w.) and high AOA (53 to $55 \mathrm{mg} \mathrm{GAE} \mathrm{g}^{-1}$ d.w.). In this respect, a well-known synergism between Se and other natural antioxidants in human organism may be considered as an additional benefit.

According to literature reports, plants are the main dietary Se source for humans, able to convert inorganic forms of the element to highly bioavailable organic ones, and in particular to Se-containing amino acids (selenomethionine, SeMet and selenocysteine, SeCys), and their methylated forms, possessing high anti-carcinogen activity [39]. As far as Apiaceae seeds are concerned, no correlation between Se and WSP content was revealed, which may be partly connected with both low Se levels and significant part of seed storage protein present in insoluble form. Nevertheless, despite the small sample analyzed, a significant correlation between Se and water soluble proteins was recorded in parsley cultivars $(\mathrm{r}=0.85$ at $p<0.05 ; n=6)$ characterized by the highest Se CV values (Tables 5 and 6).

In other cases, Se accumulation in Apiaceae seeds demonstrated no significant correlation with the total antioxidant activity (AOA) and phenolics content, which makes it suppose the need of special Se biofortification of plants for producing functional food with high se and antioxidants content.

\section{Conclusions}

The results obtained in the present research showed the high nutritional value of Apiaceae seeds, with anise, parsley, lovage and celery seeds containing the highest levels of antioxidants. The comparisons were carried out with the aim of identifying the differences of seed biochemical characteristics between species and cultivars, and may be useful to orient the Apiaceae seed utilization as dietary supplements and natural food conservatives.

Supplementary Materials: The following are available online at https:/ / www.mdpi.com/2311-752 4/7/3/57/s1, Table S1: Dates of Apiaceae seed harvesting.

Author Contributions: Conceptualization, V.K., V.P. and G.C.; data curation, V.Z.; formal analysis, V.S. and A.T.; investigation, N.G., V.K., A.M. and V.Z.; methodology, N.G., V.S., V.P. and A.T.; supervision, A.S., V.S. and V.P.; validation, G.C.; draft manuscript writing, N.G., A.M. and A.T.; manuscript revision and final editing, A.S., V.K. and G.C. All authors have read and agreed to the published version of the manuscript.

Funding: This research did not receive any grants from public, commercial or non-for-profit agencies.

Conflicts of Interest: The authors declare that they have no conflicts of interest.

\section{References}

1. Aćimović, M.; Kostadinović, M.L.; Popović, S.J.; Dojčinović, N.S. Apiaceae seeds as functional food. J. Agr. Sci. 2015, 60, 237-246. [CrossRef]

2. Ebert, A.W. Sprouts, microgreens, and edible flowers: The potential for high value specialty produce in Asia. In Proceedings of the SEAVEG 2012 Regional Symposium, Chiang Mai, Thailand, 24-26 January 2012; pp. 216-227.

3. Idowu, A.T.; Olatunde, O.O.; Adekoya, A.E.; Idowu, S. Germination: An alternative source to promote phytonutrients in edible seeds. FQS 2020, 4, 129-133. [CrossRef]

4. Koley, T.K. Microgreens from Vegetables: More Nutrition for Better Health. In Training Manual on "Advances in Genetic Enhancement of Underutilized Vegetable Crops"; Indian Institute of Vegetable Research: Varanasi, India, 18-27 October 2016; pp. 194-197.

5. Sagar, N.A.; Pareek, S.; Sharma, S.; Yahia, E.M.; Lobo, M.G. Fruit and Vegetable Waste: Bioactive Compounds, Their Extraction, and Possible Utilization Comprehensive Reviews. J. Food Sci. Food Saf. 2018, 17, 512-531. [CrossRef]

6. Ahmad, B.S.; Talou, T.; Saad, Z.; Hijazi, A.; Merah, O. The Apiaceae: Ethnomedicinal family as source for industrial uses. Ind. Crops Prod. 2017, 109, 661-671. [CrossRef]

7. Lee, J.B.; Yamagishi, C.; Hayashi, K.; Hayashi, T. Antiviral and immune stimulating effects of lignin-carbohydrate-protein complexes from Pimpinella anisum. Biosci. Biotechnol. Biochem. 2011, 75, 459-465. [CrossRef] [PubMed] 
8. Rajeshwari, C.U.; Vinay Kumar, A.V.; Andallu, B. Protective Role of Aniseeds (Pimpinella anisum L.) in Type 2 Diabetes: Under Supervision of Dr (Mrs.) B Andallu; LAP Lambert Academic Publishing: Saarbrücken, Germany, 2010.

9. Pavlyuk, I.; Stadnytska, N.; Jasicka-Misiak, I.; Górka, B.; Wieczorek, P.P.; Novikov, V. A Study of the Chemical Composition and Biological Activity of Extracts from Wild Carrot (Daucus carota L.) Seeds Waste. Res. J. Pharm. Biol. Chem. Sci. $2015,6,603-611$.

10. Fenner, M. The effects of the parent environment on seed germinability. Seed Sci. Res. 1991, 1, 75-84. [CrossRef]

11. Christova-Bagdassarian, V.; Bagdassarian, K.S.; Atanassova, M. Phenolic Profile, Antioxidant and Antibacterial Activities from the Apiaceae Family Dry Seeds. Mintage J. Pharm. Med. Sci. 2013, 2, $26-31$.

12. Martins, N.; Barros, L.; Santos-Buelga, C.; Ferreira, I.C.F.R. Antioxidant potential of two Apiaceae plant extracts: A comparative study focused on the phenolic composition. Ind. Crops Prod. 2016, 79, 188-194. [CrossRef]

13. Wangensteen, H.; Samuelsen, A.B.; Malterud, K.E. Antioxidant activity in extracts from coriander. Food Chem. 2004, 88, 293-297. [CrossRef]

14. Marques, V.; Farah, A. Chlorogenic acids and related compounds in medicinal plants and infusions. Food Chem. 2009, 113, 1370-1376. [CrossRef]

15. Sebnem, S.I.; Ayten, S. Antioxidant Potential of Different Dill (Anethum Graveolens L.) Leaf Extracts. Int. J. Food Prop. 2011, 14, 894-902. [CrossRef]

16. Kołodziejek, J. Effect of seed position and soil nutrients on seed mass, germination and seedling growth in Peucedanum oreoselinum (Apiaceae). Sci. Rep. 2017, 7, 1959. [CrossRef]

17. Martínez-Ballesta, M.C.; Egea-Gilabert, C.; Conesa, E.; Ochoa, J.; Vicente, M.J.; Franco, J.A.; Bañon, S.; Martínez, J.J.; Fernández, J.A. The Importance of Ion Homeostasis and Nutrient Status in Seed Development and Germination. Agronomy 2020, 10, 504. [CrossRef]

18. Shevchenko, J.P.; Kharchenko, V.A.; Shevchenko, G.S.; Soldatenko, A.V. Green and Spicy-Flavoring Crops; Federal Scientific Center of Vegetable Production: Moscow, Russia, 2019; ISBN 978-5-901695-80-7.

19. Golubkina, N.A.; Kekina, H.G.; Molchanova, A.V.; Antoshkina, M.S.; Nadezhkin, S.M.; Soldatenko, A.V. Plants Antioxidants and Methods of Their Determination; Infra-M: Moscow, Russia, 2020. [CrossRef]

20. Alfthan, G.V. A micromethod for the determination of selenium in tissues and biological fluids by single-test-tube fluorimetry. Anal. Chim. Acta 1984, 165, 187-194. [CrossRef]

21. Bradford, M.M. A rapid sensitive method for the quantification of microgram quantities of protein utilizing the principle of protein-dye binding. Anal. Biochem. 1976, 72, 248-254. [CrossRef]

22. Kharchenko, V.A.; Moldovan, A.I.; Golubkina, N.A.; Koshevarov, A.A.; Caruso, G. Antioxidant status of celery (Apium graveolens L.). Veg. Crops Russia 2020, 2, 82-86. (In Russian) [CrossRef]

23. Zhang, D.; Lü, H.; Chu, S.; Zhang, H.; Zhang, H.; Yang, Y.; Li, H.; Yu, D. The genetic architecture of water-soluble protein content and its genetic relationship to total protein content in soybean. Sci. Rep. 2017, 7, 5053. [CrossRef]

24. Zhao, M.; Zhang, H.; Yan, H.; Qiu, L.; Baskin, C.C. Mobilization and role of starch, protein and fat reserves during seed germination of six wild grassland species. Front. Plant Sci. 2018, 9. [CrossRef]

25. Christova-Bagdassarian, V.L.; Bagdassarian, K.S.; Atanassova, M.S. Phenolic Compounds and Antioxidant Capacity in Bulgarian Plans (dry seeds). Int. J. Adv. Res. 2013, 1, 186-197.

26. Faudale, M.; Vilasomat, F.; Bastida, J.; Poli, F.; Codina, C. Antioxidant Activity and Phenolic Composition of Wild, Edible, and Medicinal Fennel from Different Mediterranean Countries. J. Agric. Food Chem. 2008, 56, 1912-1920. [CrossRef] [PubMed]

27. Tomsone, L.; Kruma, Z. Comparison of different extraction methods for isolating phenolic compounds from lovage (Levisticum officinale L.) seeds. In Proceedings of the Conference on Innovations in Science, Education and Business, Kaliningrad, Russia, 25-27 September 2013; pp. 94-197. (In Russian).

28. Uddin, Z.; Shad, A.A.; Bakht, J.; Ullah, I.; Jan, S. In vitro antimicrobial, antioxidant activity and phytochemical screening of Apium graveolens. Pak. J. Pharm. Sci. 2015, 28, 1699-1720. [PubMed]

29. Odeh, A.; Allaf, A.W. Determination of polyphenol component fractions and integral antioxidant capacity of Syrian aniseed and fennel seed extracts using GC-MS, HPLC analysis, and photochemiluminescence assay. Chem. Pap. 2017, 71, 1731-1737. [CrossRef]

30. Sriti, J.; Aidi Wannes, W.; Talou, T.; Ben Jemia, M.; Elyes Kchouk, M.; Marzouk, B. Antioxidant properties and polyphenol contents of different parts of coriander (Coriandrum sativum L.) fruit. La Riv. Ital. Delle Sostanze Grasse 2012, LXXXIX, $253-262$.

31. Vallverdú-Queralt, A.; Regueiro, J.; Alvarenga, J.F.R.; Martinez-Huelamo, M.; Leal, L.N.; Lamuela-Raventos, R.M. Characterization of the phenolic and antioxidant profiles of selected culinary herbs and spices: Caraway, turmeric, dill, marjoram and nutmeg. Food Sci. Technol. Campinas. 2015, 35, 189-195. [CrossRef]

32. Atalar, M.N.; Karadağ, M.; Koyuncu, M.; Alma, M.H. Determination of Phenolic Components of Apium graveolens (Celery) Seeds. In Proceedings of the Aromatic Plants and Cosmetics Symposium, Iğdir, Turkey, 3-6 October 2019.

33. Tadros, L.K.; El-Rafey, H.H.; Elfadaly, H.A.; Taher, M.A.; Elhafny, A. Phenolic Profile, Essential oil Composition, Purification of Kaempferol 3-arabinofuranoside and Antimicrobial Activity of Parsley Cultivated in Dakhalia Governorate. J. Agric. Chem. Biotechnol. Mansoura Univ. 2017, 8, 183-189. [CrossRef]

34. Mert, A.; Timur, M. Essential Oil and Fatty Acid Composition and Antioxidant Capacity and Total Phenolic Content of Parsley Seeds (Petroselinum crispum) Grown in Hatay Region. Ind. J. Pharm. Educ. Res. 2017, 51, s437-s440. [CrossRef] 
35. Paven, C.S.J.; Radu, D.; Alexa, E.; Pintilie, L.S.; Rivis, A. Anethum Graveolens- an important source of antiozidant compounds for food industry. In Proceedings of the 18th International Multidisciplinary Scientific GeoConference SGEM, Albena, Bulgaria, 2-8 July 2018.

36. Ksouri, A.; Dob, T.; Belkebir, A.; Krimat, S.; Chelghoum, C. Chemical composition and antioxidant activity of the essential oil and the methanol extract of Algerian wild carrot Daucus carota L. ssp. carota. (L.). J. Mater. Environ. Sci. 2015, 6, 784-791.

37. Zhang, L.; Liu, Y. Potential interventions for novel coronavirus in China: A systematic review. J. Med. Vir. 2020, 92, 479-490. [CrossRef] [PubMed]

38. Schiavon, M.; Nardi, S.; dalla Vecchia, F.; Ertani, A. Selenium biofortification in the 21st century: Status and challenges for healthy human nutrition. Plant Soil 2020, 453, 245-270. [CrossRef] [PubMed]

39. Gupta, M.; Gupta, S. An overview of selenium content metabolism and toxicity in plant. Front. Plant Sci. $2017,7,2074$. [CrossRef] [PubMed] 